\title{
PRODUCTION AND EVALUATION OF SOME PRODUCTS PREPARED FROM IMMATURE ZAGLOUL DATE (Phoenix dactylifera)
}

Abo Samaha, O. R. ; E. M. Abou-Tour and A. A. Abdel-Nabey

Dept. of Food Sci. \& Technology, Fac. of Agric., Alex. Univ.,Alex. Egypt

\begin{abstract}
Zagloul date palm (Phoenix dactyllifera) is widely cultivated in Egypt. The immature dates (Kimri stage) with less commercial value were used for processing into date pickle, date jam and candied/ glazed/ chocolate coated dates. Chemical composition, and changes occurred during the pickling process were determined. $\mathrm{pH}$, tannins and pectin were dropped gradually and a gradual increase in titratable acidity expressed as \% lactic acid was noticed. The aforementioned products were found to be acceptable with respect to colour, taste, texture, odour and overall acceptability. These results showed that acceptable and nutritious zagloul date products can be prepared and marketed as specialty products.
\end{abstract}

Keywords: Date pickle Date jam, Candied date.

\section{INTRODUCTION}

Date (Phoenix dectylifera) is an important commercial crop in the Middle East and Arab countries especially Egypt. Date fruit is a rich source of carbohydrates comprising mainly of sugars and dietary fibre, making it one of the most nourishing natural foods available to the human. Dates are also a good source of vitamins and minerals such as $\mathrm{P}, \mathrm{Fe}, \mathrm{K}$ and a significant amount of Ca. (Kulkarni et al., 2008 and Kulkarni et al., 2010).

Dates are consumed fresh (Al-Hooti et al., 1997-a); dried (Kulkarni et al.,2008); and processed in the form of paste (Mustafa et al., 1986); Jams (Mustafa et al.,1983); juice concentrate (Kulkarni et al.,2010); glace (Sawaya et al.,1986); drinks (El-Shaarawy et al., 1986); syrup (dibis) (Abd El-Mohsen and Nezam El-Din., 1995); chutney and date relish (Al-Hooti et al.,1997-b).

In addition, dates can be used in manufacturing several products such as liquid sugar, vinegar, alcohol, yeast, confectionery and pickles (AlOgaidi et al.,1982; Khalchadourian et al., 1983; Hamad et al.,1983; Dowson and Aten, 1962; Hamad and Yousif., 1986; Hamad et al., 1986; Moustafa et al., 1986, El-Shimi and Hashimi, 1992 and Yousif and Al-Ghamdi, 1999).

The development of date fruits is divided into four stages named by their Arabic denomination, kimri, khalal, rutab and tamr. At the kimri stage, there is a rapid increase in size, weight and reducing sugars. It is the period of highest acid activity and moisture content (up to $85 \%$ ). All factors level off at the end of this stage when the fruit starts to turn yellow or red according to variety. At this stage tannins will start to precipitate and lose their astringency which makes the date already palatable (Al- Hooti et al., 1997b).

Zagloul date represents the major type of soft dates. This type of date grows well in El-Behera governorate (Edkou and Rosetta zones). The 
Abo Samaha, O. R. et al.

period between maturing and ripening expands from May to October. The environmental, soil, and water conditions as well as exposure to insects and birds affect the load of the date palm tree. At the kimri stage zagloul palm trees lose at least $15-20 \%$ of its load underneath the trees.

Very little work has been done regarding the utilization of zagloul date underneath the trees during the kimri (green) stage. So, the objectives of the present work were to utilize this type of date to produce value added products such as date pickles, date jam, candied/ glazed/ chocolate coated dates.

\section{MATERIALS AND METHODS}

Materials:

Freshly immature zagloul dates were obtained from a farm In Edkou, Al-Behera governorate at the beginning of the third week of July, 2010. Zagloul date fruits underneath the trees were collected always between 6 to 7 in the morning and transported directly to the laboratory for the experimental studies. The date fruits were sorted, washed and used for the processing into pickles, Jam, candied and glace dates.

\section{Methods:}

\section{Physical Characteristics:}

A random sample of 20 fruits of zagloul date were examined for fruit shape, colour, weight, length, width and percentage of flesh as well as calyx (cap) and pit (seed). Colour values of dates were measured by Lovibond schofield tintometer. Number/ $\mathrm{kg}$ and bulk density were also determined.

\section{Technological methods:}

Fig. (1) illustrates the flow sheets followed for preparing date pickles, date jam and candied/glazed/ chocolate coated date products.

\section{Chemical analysis:}

Proximate analysis of zagloul date including moisture, crude protein $(\mathrm{N} \times 6.25)$, crude ether extract, total ash and crude fibre were carried out according to the AOAC (1990) procedures. Carbohydrates were calculated by difference. Minerals ( $\mathrm{Fe}, \mathrm{Cu}, \mathrm{Mg}, \mathrm{Ca}, \mathrm{Mn}, \mathrm{Zn}, \mathrm{Cd}$ and $\mathrm{Pd}$ ) were measured as described in the AOAC (1990) using perkin Elmer Atomic Absorption spectrophotometer (Model 2380). On the other hand, $\mathrm{Na}$ and $\mathrm{K}$. were determined using flame photometer Model PEP7. Total soluble solids (TSS) at $20^{\circ} \mathrm{C}$ were determined by pocket refractometer (Model $2 \mathrm{WAJ}$; China). $\mathrm{pH}$ was measured by Cole Parmer $\mathrm{pH}$ meter. Titratable acidity as \% lactic acid, pectin, tannins as \% tannic acid by Folin Ciocaltu method after extracting with $70 \%$ ethanol were determined as described by Ranganna (1977). Total sugars (reducing and non-reducing) were determined using Lane and Enon procedure as stated in AOAC (1990). 
J. Food and Dairy Sci., Mansoura Univ., Vol. 2 (10), October, 2011

Fig. (1) Flow sheets of Zagloul date products 1- Slow open kettle process (Minifie 1982)

2- Quick process

595 
Abo Samaha, O. R. et al.

\section{Sensory evaluation:}

Colour, taste odour, texture, appearance and overall acceptability of date pickle, date jam and candied/ glazed date were assessed using well trained panelists of Food Science and Technolog Dept., Alex. Univ., Egypt and hedonic scale rating test as described by Ranganna (1977), was used.

\section{Statistical analysis:}

Data were transformed using square root then analyzed using randomized complete block design (R.C.B.D.). Least significant differences at 0.05 probability level (L.S.D. 0.05) was used to compare between means of the studied treatments according to Steel and Torrie (1980).

\section{RESULTS AND DISCUSSION}

\section{Physical properties of zugloul date:}

General appearance of green zagloul date in the kimri stage is shown in Fig. (2). It can be noticed that zagloul date has oblong shape. The fruits were mildly sweet with a note of astringency. The physical characteristics of fresh immature zagloul date are presented in Table (1). The weight of single fruits ranged from 7.8 to $8.2 \mathrm{~g}$. The length and width ranged from $3.59-3.61$ $\mathrm{cm}$ and $1.92-1.96 \mathrm{~cm}$, respectively. The number of fruits per kilogram was 127. The results obtained in the present study agreed well with those reported by Sawaya et al (1983)., (1986). The edible portion of zagloul date varied between 7.42 to $7.82 \mathrm{~g}$. On the other hand, the pit (seed) and calyx (cap) content varied from 0.34 to $0.42 \mathrm{~g}$ representing about $3.5 \%$ of the total weight of the fruit.

\section{Chemical composition of zagloul date}

Table (2).

The composition of the fresh immature zagloul dates is presented in

Table (1): Physical characteristics of freshly immature zagloul date fruits

\begin{tabular}{|c|c|}
\hline Character* & Value \\
\hline Total weight (g) & $7.9 \pm 0.10$ \\
\hline Length $(\mathrm{cm})$ & $3.5 \pm 0.08$ \\
\hline Width $\quad(\mathrm{cm})$ & $1.94 \pm 0.10$ \\
\hline Number per $\quad \mathrm{Kg}$ & $127 \pm 2.0$ \\
\hline Bulk density $\left(\mathrm{g} / \mathrm{cm}^{3}\right)$ & $0.65 \pm 0.01$ \\
\hline \multicolumn{2}{|l|}{ Lovibond reading } \\
\hline \begin{tabular}{|c|} 
Blue \\
\end{tabular} & \pm 0.02 \\
\hline Yellow & \pm 0.05 \\
\hline $\begin{array}{c}\text { Red } \\
\end{array}$ & $2.7 \pm 0.03$ \\
\hline Weight of flesh $(\mathrm{g})$ & $7.62 \pm 0.06$ \\
\hline Weight of calyx and pit $(\mathrm{g})$ & $0.28 \pm 0.03$ \\
\hline$\%$ of flesh & $96.46 \pm 0.03$ \\
\hline$\%$ of calyx and pit & $3.54 \pm 0.02$ \\
\hline
\end{tabular}




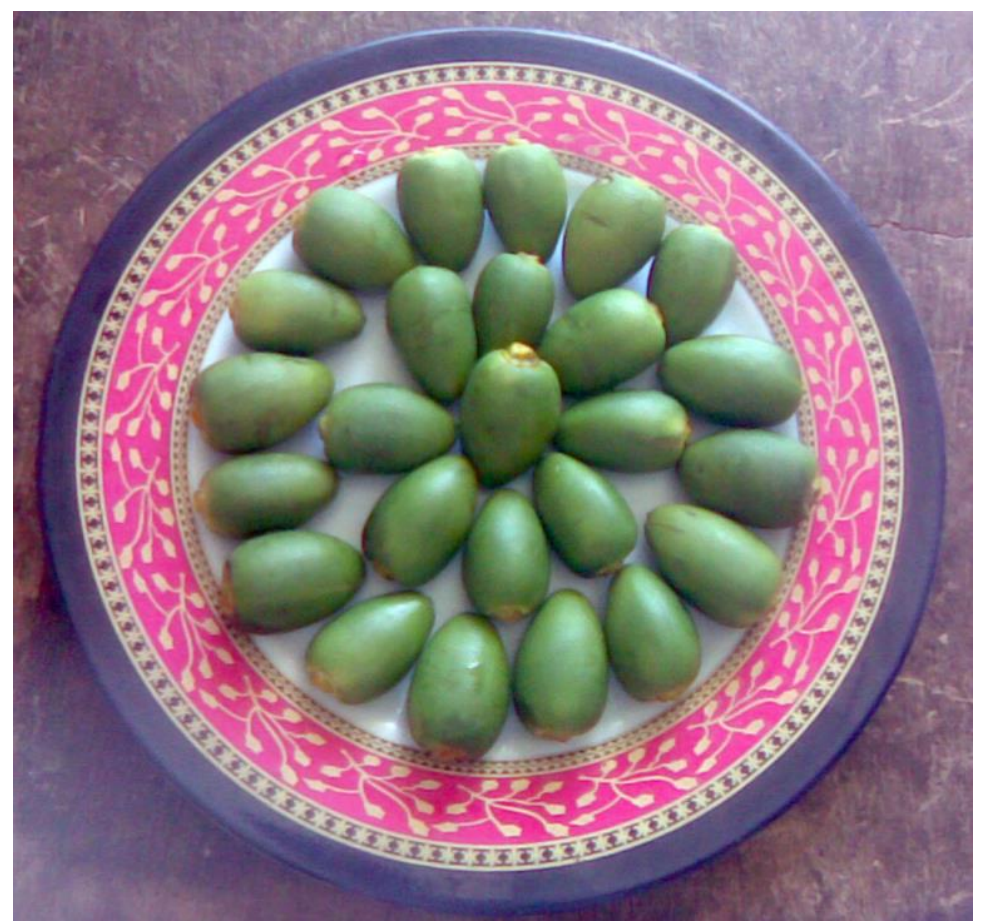

Fig. (2) General appearance of freshly immature zagloul date fruits

Data in Table (2) indicated that moisture was the major component of green zagloul date. Therefore, It was subjected for rapid deterioration if it was kept at room temperature, thus processing of immature zagloul date fruits might reduce their losses. Generally, green zagloul date contained relatively higher values of crude protein and crude fibre being 8.12 and $11.72 \%$, respectively (on dry weight basis). Slightly lower values of crude ether extract and total ash were noticed. The results indicated that freshly immature zagloul date fruits are rich in carbohydrates. Total sugars (reducing) were $7.45 \%$. No reducing sugars were detected in zagloul date at kimri stage. The results obtained here are in a good agreement with those reported by Ragab et al., (1956) and Abdalla et al (2008). Results in Table (2) also showed that green zagloul date fruits had higher content of $\mathrm{Na}, \mathrm{K}$ and $\mathrm{Mg}$. Meanwhile, $\mathrm{Ca}$, $\mathrm{Zn}, \mathrm{Fe}, \mathrm{Cu}$ and $\mathrm{Mn}$ were found in lower concentrations. These results agreed well with those reported by Farag (2004) and Abdalla et al (2008).

\section{Changes in physicochemical properties of zagloul date during pickling} process

The effect of pickling process on the $\mathrm{PH}$, titratable acidity, pectin and tannins of green zagloul date fruits is shown in Table (3).

As shown in Table (3), $\mathrm{PH}$, pectin and tannins decreased, while titratable acidity of date fruits and brining solution increased during the pickling period. It well known that during pickling process lactic acid content 
Abo Samaha, O. R. et al.

increased due to fermentation of sugars by natural flora present. At the same time, according to reverse osmosis, salt $(\mathrm{Na} \mathrm{Cl})$ transfers from the brining solution into the fruits itself. It can be noticed that green zagloul date fruits contained about $0.86 \%$ tannins as tannic acid. After four days in brining solution, tannins decreased to $0.34 \%$. These results agreed well with the results obtained by Ragab et al (1956). On the other hand, pectin decreased from $0.33 \%$ to 0.19 after 4 days in brining solution. It has been noticed that the outer skins of green zagloul date fruits were loosed in the brining solution. This indicates the end of the fruits stage of pickling in which the fruits starts to turn greenish yellow and lose their astringency which makes the dates already palatable. Also at this stage, insoluble pectin gradually converted into soluble pectin. This may be due to pectin esterase which converts insoluble pectic substances into more soluble pectin contributing to softness of the fruit (Al-Ogaidi et al, 1982 and Hamad and Yousif, 1986).

Table (2): Chemical compostion of zagloul date

\begin{tabular}{|c|c|c|}
\hline \multicolumn{2}{|c|}{ Component* } & Value \\
\hline Moisture & (\%) & $85.34 \pm 2.5$ \\
\hline Crude protein ${ }^{+}$ & $(\%)$ & $8.12 \pm 0.26$ \\
\hline Crude ether extract & (\%) & $1.34 \pm 0.59$ \\
\hline total $\mathrm{ash}^{+}$ & $(\%)$ & $2.59 \pm 0.07$ \\
\hline Carbohydrates ${ }^{* *}$ & $(\%)$ & $87.95 \pm 1.95$ \\
\hline crude fibre $^{+}$ & $(\%)$ & $11.72 \pm 0.16$ \\
\hline Total sugars & $(\%)$ & $7.45 \pm 0.46$ \\
\hline reducing & $(\%)$ & $7.45 \pm 0.37$ \\
\hline Non reducing & (\%) & $N D^{* * *}$ \\
\hline \multicolumn{3}{|l|}{ Minerals } \\
\hline $\mathrm{Fe}$ & \multirow{7}{*}{ PPm } & $3.48 \pm 0.07$ \\
\hline $\mathrm{Cu}$ & & $1.71 \pm 0.02$ \\
\hline $\mathrm{Mg}$ & & $441.49 \pm 0.50$ \\
\hline $\mathrm{Ca}$ & & $50.65 \pm 0.04$ \\
\hline $\mathrm{Nn}$ & & $1.19 \pm 0.05$ \\
\hline $\mathrm{Zn}$ & & $17.14 \pm 0.20$ \\
\hline $\mathrm{Cd}$ & & $\mathrm{ND}^{\star * *}$ \\
\hline $\mathrm{Pb}$ & \multirow{3}{*}{$\mathrm{mg} / 100 \mathrm{~g}$} & $13.95 \pm 0.35$ \\
\hline $\mathrm{Na}$ & & $900.65 \pm 0.76$ \\
\hline $\mathrm{K}$ & & $529.80 \pm 0.53$ \\
\hline
\end{tabular}

Table (3): Changes in PH, titratable acidity, pectin and tannins of zagloul date during pickling process ${ }^{\star}$

\begin{tabular}{|c|c|c|c|c|c|}
\hline \multirow{2}{*}{ Property } & \multicolumn{5}{|c|}{ Pickline period (day) } \\
\hline & 0 & 1 & 2 & 3 & 4 \\
\hline $\mathrm{PH}$ & $7.14 \pm 0.2$ & $5.57 \pm 0.3$ & $3.89 \pm 0.1$ & $3.12 \pm 0.02$ & $2.58 \pm 0.01$ \\
\hline \multicolumn{6}{|c|}{ Titratable acidity $^{\star *}$} \\
\hline Fruits & $\mathrm{ND}^{\star \star \star \star}$ & $0.0008 \pm 0.02$ & $0.002 \pm 0.02$ & $0.005 \pm 0.01$ & $0.007 \pm 0.03$ \\
\hline Solution & ND & $0.060 \pm 0.02$ & $0.108 \pm 0.03$ & $0.228 \pm 0.01$ & $0.300 \pm 0.03$ \\
\hline Pectin (\%) & $0.33 \pm 0.01$ & $0.33 \pm 0.02$ & $0.33 \pm 0.01$ & $0.29 \pm 0.02$ & $0.19 \pm 0.01$ \\
\hline Tannins ${ }^{* * *} \%$ & $0.86 \pm 0.03$ & $0.61 \pm 0.03$ & $0.56 \pm 0.01$ & $0.48 \pm 0.03$ & $0.34 \pm 0.01$ \\
\hline
\end{tabular}




\section{Sensory evaluation of zagloul date products}

The general appearance of zagloul date products are shown in Figs. $(3,4)$.

\section{A- Date Pickle}

The sensory evaluation of the finished product of date pickle is shown in Table (4).

Table (4): Changes in sensory properties of date pickle during storage*

\begin{tabular}{|c|c|c|c|c|c|}
\hline \multirow{2}{*}{$\begin{array}{l}\text { Storage period } \\
\text { (work) }\end{array}$} & \multicolumn{4}{|c|}{ Characters } & \multirow{2}{*}{$\begin{array}{c}\text { Overall } \\
\text { Acceptability }\end{array}$} \\
\hline & Colour & Taste & Texture & Odour & \\
\hline 2 & $8.13^{a}$ & $7.60^{a}$ & $8.20^{\mathrm{a}}$ & $7.87^{a}$ & $8.0^{\mathrm{a}}$ \\
\hline 4 & $8.0^{\mathrm{a}}$ & $7.86^{a}$ & $8.13^{\mathrm{a}}$ & $7.93^{\mathrm{a}}$ & $8.07^{a}$ \\
\hline 6 & $8.13^{\mathrm{a}}$ & $7.86^{\mathrm{a}}$ & $8.33^{\mathrm{a}}$ & $8.00^{\mathrm{a}}$ & $8.20^{\mathrm{a}}$ \\
\hline 8 & $8.46^{\mathrm{a}}$ & $7.93^{a}$ & $8.06^{a}$ & $8.33^{\mathrm{a}}$ & $8.27^{\mathrm{a}}$ \\
\hline
\end{tabular}

Means in the same column followed by the same letter(s) are not significantly different according to L.S.D. values 0.05

It was obvious that panelists accepted the green zagloul date pickle kept in the pickling solution even after 8 weeks of storage at ambient temperature $\left(22 \pm 2^{\circ} \mathrm{C}\right)$.

The panelists did not notice any significant differences in the studied organoleptic properties during this storage period.

\section{B- Date Jam}

The sensory evaluation of the finished products of date jam is shown in Table (5).

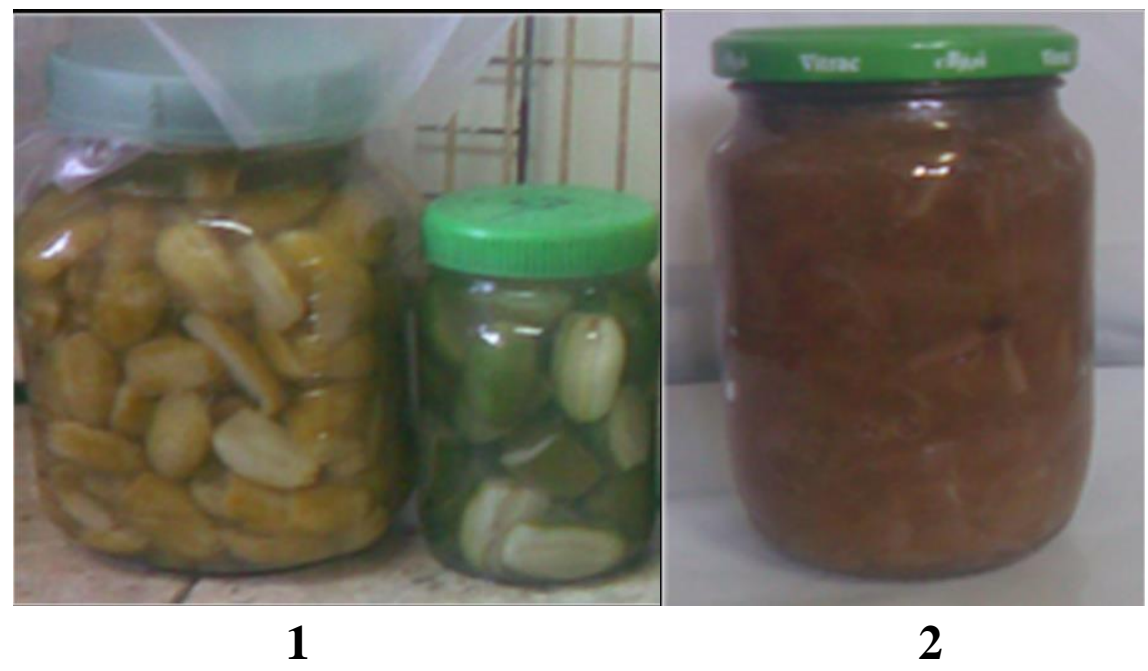

Fig (3): General appearance of date pickle (1) and date Jam (2) 


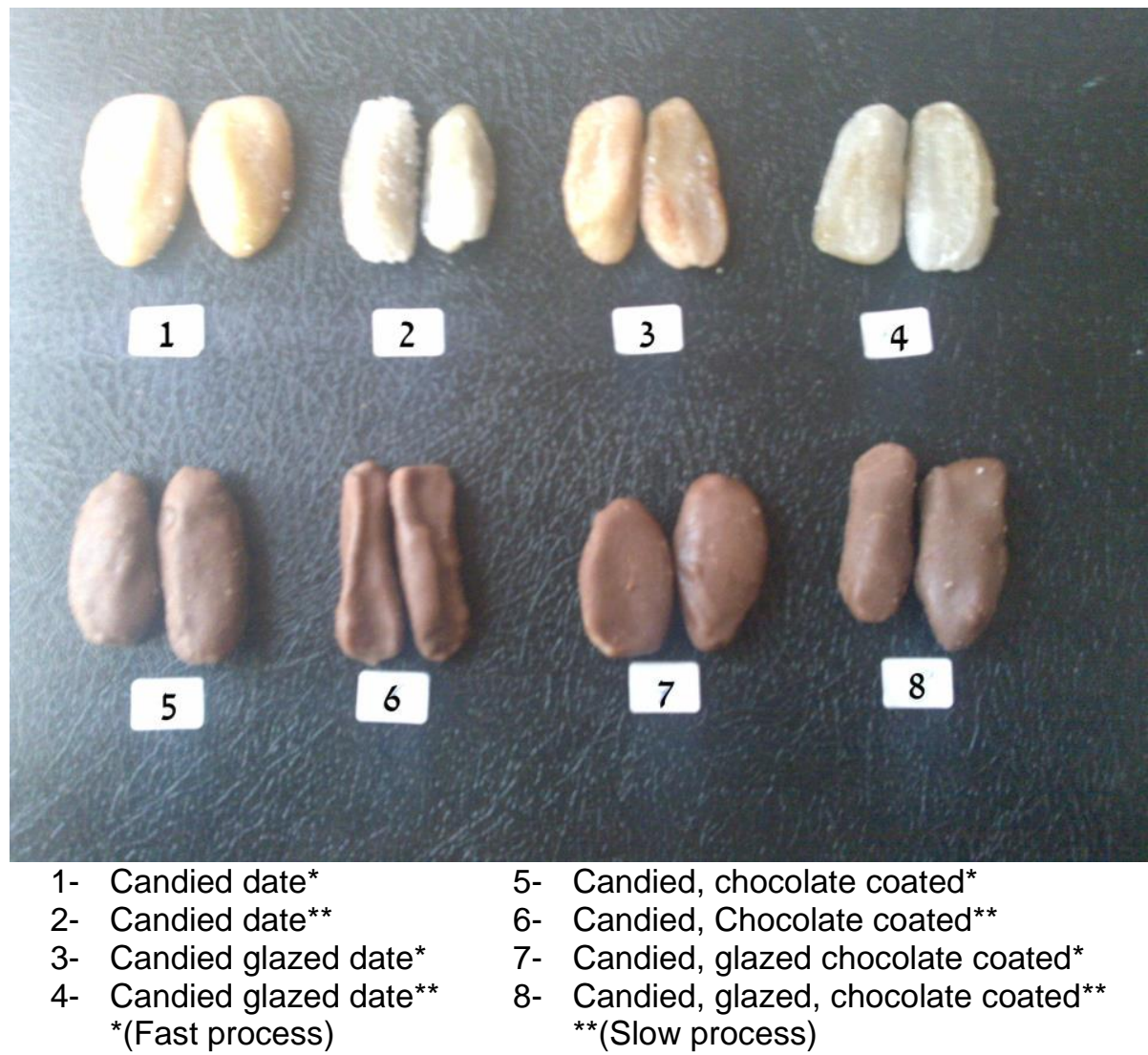

Fig (4): General appearance of Candied/ glazed/ chocolate coated date products

Table (5): Organoleptic Properties of jams Produced from green Zagloul date

\begin{tabular}{|c|c|c|c|c|c|}
\hline \multirow{2}{*}{ Tested Products } & \multicolumn{4}{|c|}{ Characters } & \multirow{2}{*}{$\begin{array}{c}\text { Overall } \\
\text { Acceptability }\end{array}$} \\
\hline & Colour & Taste & Texture & Odour & \\
\hline $\begin{array}{l}\text { Mashed without } \\
\text { Flavoring agent }\end{array}$ & $7.73^{\mathrm{a}}$ & $8.27^{\mathrm{ab}}$ & $8.33^{a b}$ & $8.27^{a}$ & $8.07^{b}$ \\
\hline $\begin{array}{l}\text { Mashed with } \\
\text { Flavoring agent }\end{array}$ & $6.80^{\mathrm{b}}$ & $7.73^{b}$ & $7.80^{\mathrm{b}}$ & $7.20^{\mathrm{b}}$ & $7.47^{b}$ \\
\hline Halves & $8.4^{\mathrm{a}}$ & $8.80^{a}$ & $8.67^{\mathrm{a}}$ & $8.80^{\mathrm{a}}$ & $9.13^{\mathrm{a}}$ \\
\hline \begin{tabular}{|ll} 
L.S.D & 0.05 \\
\end{tabular} & 0.91 & 0.67 & 0.68 & 0.62 & 0.83 \\
\hline
\end{tabular}

Means in the same column followed by the same letter(s) are not significantly different according to L.S.D. values 0.05

As shown from Table (5), Panelists accepted all the jam products prepared either in mashed form or in halves. The overall acceptability of jam containing extracts of cinnamon and cloves was less acceptable comparing with the other two jam products. No significant differences were noticed in colour, taste, odour and texture between mashed date jam without flavouring agent and date jam in halves. 


\section{C- Candied/ glazed/ chocolate coated date products}

The sensory evaluation of the finished products of candied / glazed/ chocolate coated date products is shown in Table (6).

According to the obtained data it can be noticed that candied, Chocolate coated as well as candied, glazed and chocolate coated date products prepared by the two processes (slow open kettle process and the quick process) were more acceptable than the candied date only or the candied and glazed date products. The results indicated that glazing process followed by chocolate coating improved the organoleptic properties of candied date produced by the aforementationed processes. Also, the data revealed that no significant differences were noticed between candied chocolate coated and candied glazed chocolate coated date products prepared either by the slow or the fast process.

Table (6): Organoleptic Properties of Candied/ glazed/ chocolate coated date products*

\begin{tabular}{|c|c|c|c|c|c|}
\hline \multirow{2}{*}{ Tested Products } & \multicolumn{4}{|c|}{ Characters } & \multirow{2}{*}{$\begin{array}{c}\text { Overall } \\
\text { Acceptability }\end{array}$} \\
\hline & Colour & Taste & Texture & Odour & \\
\hline \multicolumn{6}{|l|}{ Candied } \\
\hline 1- $\quad$ Slow process & $6.30^{c}$ & $6.85^{\mathrm{b}}$ & $7.15^{b}$ & $6.85^{\mathrm{b}}$ & $6.20^{\mathrm{b}}$ \\
\hline 2- $\quad$ Fast process & $7.30^{\mathrm{b}}$ & $6.50^{\mathrm{b}}$ & $7.35^{b}$ & $7.06^{\mathrm{b}}$ & $6.80^{\mathrm{b}}$ \\
\hline \multicolumn{6}{|l|}{ Candied glazed } \\
\hline 1- Slow & $6.85^{\mathrm{bc}}$ & $6.65^{\mathrm{b}}$ & $7.0^{\mathrm{b}}$ & $6.80^{\mathrm{b}}$ & $6.70^{\mathrm{b}}$ \\
\hline 2- $\quad$ Fast & $7.40^{\mathrm{b}}$ & $7.05^{b}$ & $7.12^{b}$ & $6.95^{\mathrm{b}}$ & $7.15^{b}$ \\
\hline \multicolumn{6}{|l|}{ Candied, chocolate } \\
\hline 1- $\quad$ Slow & $8.65^{a}$ & $7.80^{\mathrm{a}}$ & $8.05^{\mathrm{ab}}$ & $8.15^{\mathrm{a}}$ & $8.25^{a}$ \\
\hline $2-\quad$ Fast & $8.40^{\mathrm{a}}$ & $7.70^{\mathrm{ab}}$ & $8.05^{\mathrm{ab}}$ & $7.95^{\mathrm{a}}$ & $8.15^{a}$ \\
\hline \multicolumn{6}{|c|}{ Candied, glazed and chocolate coated } \\
\hline 1- $\quad$ Slow & $8.65^{a}$ & $8.05^{a}$ & $7.85^{\mathrm{a}}$ & $8.40^{\mathrm{a}}$ & $8.45^{a}$ \\
\hline 2- $\quad$ Fast & $8.50^{\mathrm{a}}$ & $8.40^{\mathrm{a}}$ & $8.15^{\mathrm{a}}$ & $8.25^{a}$ & $8.40^{\mathrm{a}}$ \\
\hline L.S.D. 0.05 & 0.67 & 0.71 & 0.78 & 0.71 & 0.86 \\
\hline
\end{tabular}

Means in the same column followed by the same letter(s) are not significantly differen according to L.S.D. values 0.05

1- slow open kettle process

2- Quick process

It may be concluded that date pickle, date jam as well as candied/ glazed/ chocolate coated date products with desirable sensory quality could be prepared from immature green zagloul date underneath the trees fruits (Kimri stage).

\section{Acknowledgment}

The authors are grateful to Dr. Ahmed Rafik El-Mahdy and Dr. Ahmed A. Domeer, Professors of Food Science and Technology, Food Science and Technology Dept., Faculty of Agriculture, El-Shatby, Alexandria University for their constant encouragement during the course of investigation. 


\section{REFERENCES}

Abdalla, M.Y.; Abo-El-sooud, A.A.; Ammar, M.E.F., Rashid, M.F and Saber, F.M.M. (2008). Palm tree: Agriculture and Service. (In Arabic) Agricultural Technical Report, Ministry of Agriculture, A.R.E.

Abd El-Mohsen, M.M. and Nezam El-Din (1995). Technological study on dibis production from the Siwi date. Egyptian J. of Food Science 23 : 229 239

Al-Hooti, S.; Sidhu, J.S.; Al-Otaib, J.; Al-Ameeri, H. and Qabazard, H. (1997a). Utilization of date fruits at different maturity stages for variety pickles. Advn. Food Sci. 19: $1-7$.

Al-Hooti; S.; Sidhu, J.S.; Al-Otaib, J.; Al-Ameeri, H. and Qabazard, H. (1997b). Processing of some important date cultivars grown in United Arab Emirates into chutney and relish. J. Food proc. Preserv. 21: $51-68$.

Al-Ogaidi, H.K., Albardie, J. and Abdel-Maseih, M. (1982). Possibility of pickling zahdi dates at al-kimri stage. J. of Research for Agric and water resources (Iraq) 1:51-56.

Association of Official Analytical Chemists (1990). Official Methods of Analysis AOAC $15^{\text {th }} \mathrm{Ed}$. Washington DC, USA

Dowson, V.H. and Aten, A. (1962). Date Handling, Processing and Packaging, FAO, Rome.

El-Shaarawy, M.I.; Messalam, A.S.; Nakhal, H.M. and Wahdan, A.N (1986). Preparation of date drinks. Proceedings of $2^{\text {ed }}$ symposium on date palm in Saudi Arabia, KFU, Al-Hassa, 273 - 282.

El-Shimi, N. M. and Hashimi, J. (1992). Utilization of date paste in cake product. Menofiya J. Agric. Res., 17: 1155 - 1168.

Farag, K.M. (2004). Palm tree: Science, Culture and Tradition (In Arabic) Zayed center for tradition and History, UAE.

Hamad, A.M., Mustafa, A.I. and Al-Kahtani, M.S. (1983). Possibility of utilize date syrup as a sweetening and flavouring agent in ice cream making. Proceedings of $1^{\text {st }}$ symposium on date palm in Saudi Arabia, KFU, ALHassa, $544-550$.

Hamad, A.M. and Yousif, A.K. (1986). Evaluation of brine and salt-stock pickling of two date varieties in the kimri stage. Proceedings of $2^{\text {ed }}$ symposium on date palm in Saudi Arabia, KFU, Al-Hassa, $245-257$

Hamad, A.M.; Al-Kanhal, H.A., and Al-Shaieb, I. (1986). Possibility of utilizing date purée and date pieces in the production of milk frozen desserts. Proceedings of $2^{\text {ed }}$ symposium on date palm in Saudi Arabia, KFU., AlHassa, 181- 187.

Khalchadourian, H.A.; Sawaya, W.N.; Kalil, J.K.; Sali, W.M. and Mashadi, A.A. (1983). Utilization of dates (Phoenix dactylifera L) grown in the kingdom of Saudi Arabia in various date products. Proceedings of $1^{\text {st }}$ symposium on date palm in Saudi Arabia, KFU., Al-Hassa, 504-518.

Kulkarni, S.G., Vijayanand, P.; Aksha, M.; Reena, P and Ramana, K. V.R. (2008). Effect of dehydration on the quality and storage stability of immature dates (Phoenix dactylifera). LWT Food Sci. Technol. 41: 278 $-283$.

Kulkarni, S.G.; Vijayanand, P. and Shubha, L. (2010). Effect of processing of dates into date Juice concentrate and appraisal of its quality characteristics. J. Food Sci. Technol. 47: 157 - 161. 
Minifie, B.W. (1982). Chocolate, Cocoa and Confectionery: Science and Technology. AVI Publishing CO. Westport Conn. Chicago, USA.

Mustafa, A.I., Hamad, A.M. and Al-Kahtani, M. (1983). Date varieties for Jam productions. Proceedings of $1^{\text {st }}$ symposium on date palm in Saudi Arabia, KFU., Al- Hassa, 496 - 502.

Mustafa, A.I., Yousif, A.K. and Whadan, A.N. (1986). Utilization of date paste in bakery products. Proceedings of $2^{\text {ed }}$ symposium on date palm in Saudi Arabia, KFU. Al-Hassa, 207 - 218.

Ragab, M.H.H.; El-Tabey Shehata, A. M. and Sedky, A. (1956). Studies on Egyptian dates. Chemical changes during development and ripening of six varieties. Food Technol. 10: $407-410$.

Ranganna, S. (1977). Manual of analysis of fruit and vegetable products. Mc Grow-Hill Pub. Co. LTd., New Delhi.

Sawaya, W.N.; Safi, W.M.; Khalil, J.K. and Mashadi, A.S. (1983). Physical measurement, proximate analysis and nutrient elements content of twenty-five date cultivars grown in Saudi Arabia at the Khalal (Mature) and Tamer (Ribe) Stages. Proceedings of $1^{\text {st }}$ symposium on date in Saudi Arabia, KFU, Al-Hassa, $454-467$.

Sawaya, W,N., Khalil, J.K.; Al- Shalhat, A.F. and Ismail, A.A (1986). Processing of glace dates. Proceedings of $2^{\text {ed }}$ symposium on date palm in Saudi Arabia, KFU, Al-Hassa, 113 - 120.

Steel, R.G.D. and Torrie, J.H. (1980). Principles and Procedures of statistics, New York. Mc Graw-Hill.

Yousif, A.K. and Al-Ghamdi, A.S. (1999). Suitability of some date cultivars for jelly making. J. Food Sci. Technol. 36: $515-518$.

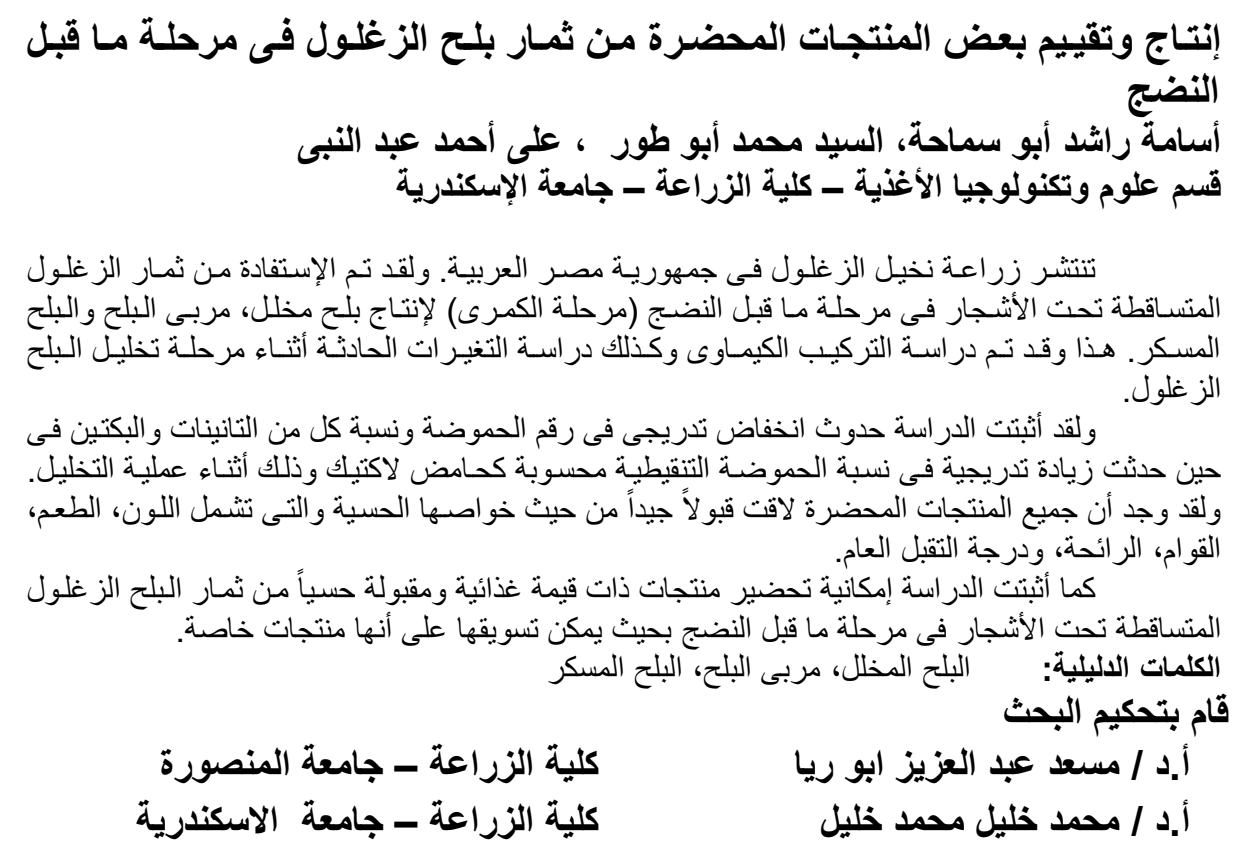


Abo Samaha, O. R. et al. 